\title{
Production of Biomass and Bioactive Compounds from Cell Suspension Cultures of Eurycoma longifolia in Balloon Type Bubble Bioreactors
}

\author{
Kyu-Man Shim ${ }^{1}$, Hosakatte Niranjana Murthy ${ }^{1,2}$, So-Young Park ${ }^{1}$, Ibrahim Rusli ${ }^{3}$, and Kee-Yoeup Paek ${ }^{1 *}$ \\ ${ }^{1}$ Research Center for the Development of Advanced Horticultural Technology, Chungbuk National University, Cheongju 361-763, Republic of Korea \\ ${ }^{2}$ Department of Botany, Karnatak University, Dharwad 580003, India \\ ${ }^{3}$ Agrotechnology and Bioscience Division, Malaysian Nuclear Agency, Bangi, Kajang, Selangor, Malaysia
}

\begin{abstract}
Eurycoma longifolia is an important rare medicinal plant that contains valuable bioactive compounds. In the present study, cell suspension culture of E. longifolia was established for the production of biomass and phenolic compounds. Various medium parameters, such as concentration of auxin, salt strength of the medium, and sucrose and nitrogen concentrations, were optimized for the production of biomass at the flask-scale level. Full strength Murashige and Skoog (MS) medium supplemented with $3.0 \mathrm{mg} \cdot \mathrm{L}^{-1}$ naphthaleneacetic acid (NAA), 3\% (w/v) sucrose, 0:60 $\mathrm{NH}_{4}^{+}: \mathrm{NO}_{3}{ }^{-}$was found suitable for biomass accumulation. Based on the optimized flask-scale parameters, cell suspension cultures were established in balloon-type bubble bioreactors, and bioprocess parameters such as inoculum density and aeration rate were optimized. Inoculum density of $50 \mathrm{~g} \cdot \mathrm{L}^{-1}$ and increasing aeration rate from 0.05 to $0.3 \mathrm{vvm}$, with increases every 7 days, were suitable for the accumulation of both biomass and phenolic compounds. With the optimized conditions, $14.70 \mathrm{~g} \cdot \mathrm{L}^{-1}$ dry biomass, $10.33 \mathrm{mg} \cdot \mathrm{g}^{-1} \mathrm{DW}$ of phenolics and $3.89 \mathrm{mg} \cdot \mathrm{g}^{-1} \mathrm{DW}$ of flavonoids could be achieved. Phenolics isolated from the cell biomass showed optimal free radical scavenging activity.
\end{abstract}

Additional key words: Aeration volume, inoculum, phenolics, secondary metabolites, Tongkat ali

\section{Introduction}

Eurycoma longifolia (family Simaroubaceae) is popularly known as 'Tongkat Ali' is an important medicinal plant in Southeast Asia which is used for its antipyretic, anti-malarial, anti-ageing and restorative activities (Perry, 1980). Major chemical constituents of $E$. longifolia are phenolics, alkaloids and triterpenoids (Bhat and Karim, 2010). Phenolics which are isolated from $E$. longifolia show profound antioxidant activities and are considered responsible for anti-ageing effect (Purwantiningsih et al., 2011). Various E. longifolia based health supplements are available in the market. Due to its increased demand and overexploitation, this plant has been declared as endangered in Malaysia.

Cell and organ cultures are promising alternatives for the production of valuable bioactive compounds in plants which are rare and difficult to cultivate (Ramachandra Rao and Ravishankar, 2002; Murthy et al., 2014). Production of biomass and bioactive compounds through cell cultures can meet the demand of pharmaceutical industry and also accounts for little ease on natural stand. Therefore, major objective of present study was to establish cell suspension cultures using bioreactor system. Initially we established cell suspension cultures in Erlenmeyer flasks and optimized the various chemical parameters such as growth regulators, medium salt strength, sucrose and nitrogen concentration for accumulation biomass. After establishing the medium parameters at flask-scale cultures, cell suspension cultures were initiated in balloon type bubble bioreactors and bioprocess parameters such as inoculum density and aeration

\footnotetext{
*Comesponding author: paekky@chungbuk.ac.kr
}

※ Received 8 June 2014; Revised 19 October 2014; Accepted 23 October 2014. This study was supported by a grant of Korea Healthcare Technology R\&D project, Ministry of Health and Welfare, Republic of Korea (Grant No. A103017). One of us (Dr. H. N. Murthy) is thankful to Ministry of Education, Science and Technology, Republic of Korea for the award of Brain Pool Fellowship (131S-4-3-0523) and this paper was studied with the support of Ministry of Science, ICT and Planning (MSIP).

(C) 2015 Korean Society for Horticultural Science 
volume were worked out for the accumulation of both biomass and bioactive compounds.

\section{Materials and Methods}

\section{Plant material}

In vitro grown plant material of $E$. longifolia was supplied by Dr. Ibrahim Rusli, Malaysian Nuclear Agency, Bangi, Kajang, Selangor, Malaysia.

\section{Establishment of cell suspension cultures}

Callus cultures were raised from root segments of $E$. longifolia on Murashige and Skoog (MS, 1962) medium gelled with $0.8 \%(\mathrm{w} / \mathrm{v})$ agar and supplemented with 1.0 $\mathrm{mg} \cdot \mathrm{L}^{-1}$ 2, 4-dichloroacetic acid (2, 4-D) and 3\% (w/v) sucrose. Cultures were incubated in the growth chambers at $25 \pm 1^{\circ} \mathrm{C}$, with a $16 \mathrm{~h} \mathrm{light}\left(40 \mu \mathrm{mol} \cdot \mathrm{m}^{-2} \cdot \mathrm{s}^{-1}\right)$ and $8 \mathrm{~h}$ dark photoperiod cycle provided by $40-\mathrm{W}$ white fluorescent tubes. The calli masses were subcultured once in four weeks to fresh medium to make the callus friable (Fig. 1A). Cell suspension cultures were initiated by taking $5 \mathrm{~g}$ cells as inoculum in $100 \mathrm{~mL}$ MS liquid medium with $30 \mathrm{~g} \cdot \mathrm{L}^{-1}$ sucrose in $400 \mathrm{~mL}$ Erlenmeyer flasks (Fig. 1B). The cultures were kept for continuous agitation at $110 \mathrm{rpm}$ on the orbital shaker and incubated at $25 \pm 1^{\circ} \mathrm{C}$, with a $16 \mathrm{~h}$ $\left(40 \mu \mathrm{mol} \cdot \mathrm{m}^{-2} \cdot \mathrm{s}^{-1}\right)$ light and $8 \mathrm{~h}$ dark photoperiod cycle provided by $40-\mathrm{W}$ white fluorescent tubes.

In the first set of experiments, the effect of indole-3-butyric acid (IBA) and naphthalene acetic acid (NAA) in the range of $0.5,1.0,3.0,5.0$ and $7.0 \mathrm{mg} \cdot \mathrm{L}^{-1}$ were tested on biomass accumulation. In another set of experiments, the effects of MS salt strength ranging 0.5, 1.0, 1.5 and 2.0 concentrations were tested on biomass growth. In the third set, the effect of sucrose concentrations $[0,1,3,5$ and $7 \%(w / v)]$ was assessed on the production of biomass. The effect of nitrogen concentration $\left[\mathrm{NH}_{4}{ }^{+}: \mathrm{NO}_{3} ; 0: 30,5: 25,10: 20,15: 15,20: 10\right.$,

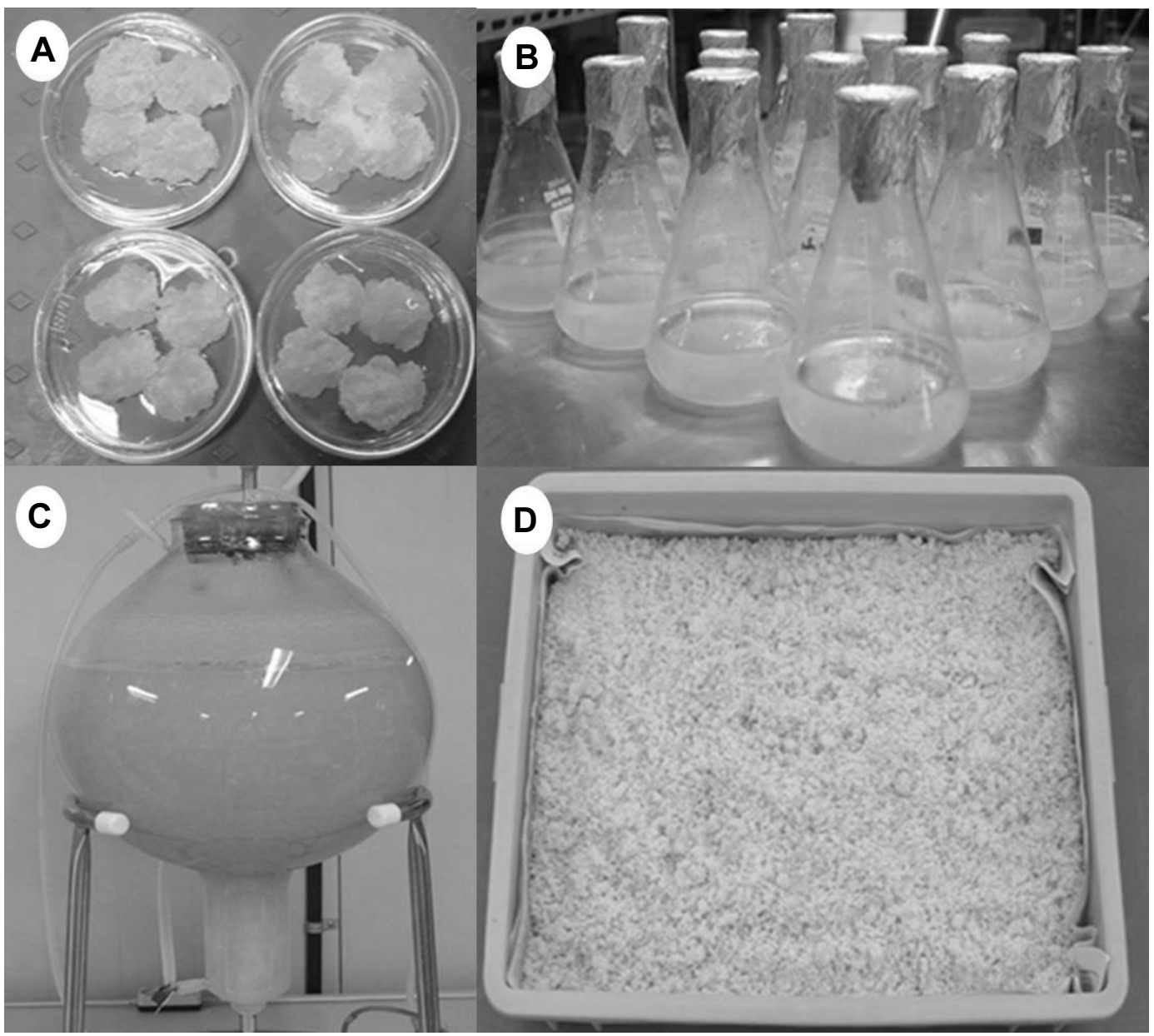

Fig. 1. E. longifolia cell suspension culture: A. Callus masses. B. Cell suspension cultures in flasks. C. Cell suspension cultures in airlift bioreactor. D. Biomass harvested from bioreactor cultures. 
25:5 and 30:0 mM] was tested for the production of biomass in the fourth set of experiments. The concentration of ammonium $\left(\mathrm{NH}_{4}^{+}\right)$nitrogen and nitrate nitrogen $\left(\mathrm{NO}_{3}{ }^{-}\right)$ were maintained by using $\mathrm{NH}_{4} \mathrm{Cl}(20 \mathrm{M})$ and $\mathrm{KNO}_{3}(40 \mathrm{M})$ solutions. Cell suspension cultures were initiated by taking $5 \mathrm{~g}$ of inoculum in $100 \mathrm{~mL}$ MS liquid medium supplemented in $400 \mathrm{~mL}$ Erlenmeyer flasks. The $\mathrm{pH}$ of the medium was adjusted to $5.6 \pm 0.2$ before sterilization using $0.1 \mathrm{~N}$ sodium hydroxide $(\mathrm{NaOH})$ and $0.1 \mathrm{~N}$ hydrochloric acid $(\mathrm{HCl})$. The cultures were kept for continuous agitation at $110 \mathrm{rpm}$ on the orbital shaker and incubated at $25 \pm 1^{\circ} \mathrm{C}$, with a $16 \mathrm{~h}$ light $\left(40 \mu \mathrm{mol} \cdot \mathrm{m}^{-2} \cdot \mathrm{s}^{-1}\right)$ and $8 \mathrm{~h}$ dark photoperiod cycle provided by $40-\mathrm{W}$ white fluorescent light for 30 days.

\section{Establishment of cell suspension cultures in balloon type bubble bioreactors}

After optimization of growth regulator, salt strength (MS medium), sucrose and nitrogen concentration of medium, suspension cultures were established in the $5 \mathrm{~L}$ balloon type bubble bioreactors containing $3 \mathrm{~L}$ of full strength modified MS medium supplemented with $3.0 \mathrm{mg} \cdot \mathrm{L}^{-1} \mathrm{NAA}$, $3 \%(\mathrm{w} / \mathrm{v})$ sucrose, $60 \mathrm{mM} \mathrm{KNO}_{3}$ for accumulation of biomass and bioactive compounds. As inoculum, $50 \mathrm{~g} \cdot \mathrm{L}^{-1}$ cells (fresh biomass) was used, the aeration rate in bioreactors was automatically adjusted to $0.1 \mathrm{vvm}$ (air volume per culture volume) using air flow meters (RMA series; Dwyer Instruments Inc., Michigan, USA) and cultures were maintained for 30 days. The effect of inoculum density viz. 40, 50, 60, 70 and $80 \mathrm{~g} \cdot \mathrm{L}^{-1}$ was verified in one set of experiments. In another set of experiments, bioreactor cultures were established as described above, but here the cultures were aerated at a rate of $0.05,0.1,0.2$, and $0.3 \mathrm{vvm}$ constant air supply throughout the culture period, or with an increased rate of air supply from 0.05 to $0.3 \mathrm{vvm}$ every 7 -days to verify the most appropriate aeration rate for the accumulation of biomass and phenolics. All the bioreactors were maintained for 30 days at $25 \pm 1^{\circ} \mathrm{C}$, with a $16 \mathrm{~h}\left(40 \mu \mathrm{mol} \cdot \mathrm{m}^{-2} \cdot \mathrm{s}^{-1}\right)$ light and $8 \mathrm{~h}$ dark photoperiod cycle provided by $40-\mathrm{W}$ white fluorescent tubes. After 30 days, growth parameters such as fresh weight, dry weight and growth ratio and the content of bioactive compounds polyphenolics and flavonoids were assessed.

\section{Determination of cell biomass}

After 30 days of culture, the cells were separated from the medium through a stainless steel sieve. The fresh biomass measured after blotting away the surface water. The dry weight was recorded after drying the cells at $60^{\circ} \mathrm{C}$ for
$24 \mathrm{~h}$. The growth ratio was calculated as follows: [harvested dry weight (g) - inoculated dry weight (g)/inoculated dry weight].

\section{Determination of total phenolic content}

The total phenolic content in the methanolic cell extract was determined as described by Slinkard and Singleton (1977). Methanolic extract $(0.05 \mathrm{~mL})$ was added with 2.25 $\mathrm{mL}$ distilled water and $0.1 \mathrm{~mL}(2 \mathrm{~N})$ Folin-Ciocalteu reagent and solution was allowed to stand for $6 \mathrm{~min}$ at room temperature. The absorbance was measured at $760 \mathrm{~nm}$ with a UV visible spectrophotometer (UV-1650PC; Shimadzu, Kyoto, Japan). The amount of phenolic content was calculated with reference to standard curve of gallic acid solution (Sigma Chemical Co., St. Louis, MO, USA).

\section{Determination of total flavonoid content}

The total flavonoid content in the methanolic cell extract was determined by following the method of Zhuang et al. (1992). The methanolic extract $(0.25 \mathrm{~mL})$ or a (+)-catechin standard solution (Sigma Chemical Co., St. Louis, MO, USA; $0.25 \mathrm{~mL}$ ) was added with $1.25 \mathrm{~mL}$ distilled water and $0.075 \mathrm{~mL} \mathrm{5 \%}(\mathrm{w} / \mathrm{v})$ aluminum chloride solution, and the mixture was allowed to stand for $5 \mathrm{~min}$ and then $0.5 \mathrm{~mL}$ of $1 \mathrm{M}$ sodium hydroxide solution was added. The absorbance was measured at $510 \mathrm{~nm}$ with a UV-visible spectrophotometer (UV-1650PC; Shimadzu, Kyoto, Japan). The absorbance measurements were integrated by comparison with an external standard calibration curve.

\section{Establishment of extraction method}

Heat reflex method was followed and extraction was carried out in $100 \mathrm{~mL}$ round bottom flask fitted with a cooling condenser (Buchi extraction unit E-812, Flawil, Switzerland). $0.5 \mathrm{~g}$ powdered material was placed in a round bottom flask and extraction was carried out at 80 $\pm 1^{\circ} \mathrm{C}$ for $1 \mathrm{~h}$ using $50 \mathrm{~mL}$ of distilled water, $40,60,80$ and $100 \%$ of methanol and ethanol to find out the suitability of solvent for extraction of total phenolics and flavonoids. In all the above experiments, when the extraction was complete, the extract after cooling was filtered using two layers of Whatmann no. 1 filter paper. The residue obtained was re-extracted one more time using fresh solvent under the conditions mentioned above. The condenser was washed with $20 \mathrm{~mL}$ of solvent. The washings were added to the extract, and then the flask was filled up to volume. The combined extract $(100 \mathrm{~mL})$ was used for total phenols and flavonoids. 


\section{Scavenging effect of 1,1-diphenyl-2-picrylhydrazyl (DPPH)}

Free radical scavenging capacity was evaluated according to the previously reported procedure using 1, 1-diphenyl-2picrylhydrazyl (DPPH) (Brand-William et al., 1995). The initial concentration of DPPH radicals was $100 \mu \mathrm{M}$ for all antioxidant-radical reactions. The antioxidant-radical reactions were conducted for $5 \mathrm{~min}$ in the dark at an ambient temperature. The decrease in absorbance at $517 \mathrm{~nm}$ was measured against a blank of pure ethanol to estimate the radical scavenging capacity of each antioxidant sample.

\section{Statistical analysis}

All experiments were set up in a completely randomized design and the data were collected from three replicates. Mean values were subjected to Duncan's multiple range test using SPSS software (version 9.0).

\section{Results}

\section{Optimization of medium parameters in flask-scale cell suspension cultures}

To understand the growth characteristics of suspended cells of E. longifolia in shake flasks, the effect of NAA and IBA was tested and the results revealed that supplementation

Table 1. Eurycoma longifolia flask-scale cell suspension culture: effect of auxins on accumulation of biomass after 30 days of culture.,

\begin{tabular}{lcccc}
\hline Auxin & $\begin{array}{c}\text { Concentration } \\
\left(\mathrm{g} \cdot \mathrm{L}^{-1}\right)\end{array}$ & $\begin{array}{c}\text { Fresh weight } \\
\left(\mathrm{g} \cdot \mathrm{L}^{-1}\right)\end{array}$ & $\begin{array}{c}\text { Dry weight } \\
\left(\mathrm{g} \cdot \mathrm{L}^{-1}\right)\end{array}$ & $\begin{array}{c}\text { Growth } \\
\text { ratio }\end{array}$ \\
\hline $2,4-\mathrm{D}$ & 1.0 & $96.7 \mathrm{c}$ & $4.9 \mathrm{~d}$ & $1.38 \mathrm{~cd}$ \\
NAA & 0.5 & $107.8 \mathrm{bc}$ & $6.3 \mathrm{c}$ & $2.04 \mathrm{c}$ \\
& 1.0 & $116.9 \mathrm{~b}$ & $6.9 \mathrm{~b}$ & $2.32 \mathrm{~b}$ \\
& 3.0 & $131.8 \mathrm{a}$ & $7.6 \mathrm{a}$ & $2.68 \mathrm{a}$ \\
& 5.0 & $100.0 \mathrm{c}$ & $5.2 \mathrm{~d}$ & $1.50 \mathrm{c}$ \\
& 7.0 & $97.4 \mathrm{c}$ & $5.3 \mathrm{~d}$ & $1.55 \mathrm{c}$ \\
& 0.5 & $52.6 \mathrm{e}$ & $1.4 \mathrm{f}$ & $0.00 \mathrm{e}$ \\
& 1.0 & $63.9 \mathrm{~d}$ & $3.7 \mathrm{e}$ & $0.77 \mathrm{~d}$ \\
& 3.0 & $75.1 \mathrm{~d}$ & $4.8 \mathrm{~d}$ & $1.33 \mathrm{~cd}$ \\
& 5.0 & $74.0 \mathrm{~d}$ & $4.2 \mathrm{e}$ & $1.01 \mathrm{~d}$ \\
& 7.0 & $62.6 \mathrm{~d}$ & $3.6 \mathrm{e}$ & $0.72 \mathrm{~d}$ \\
\hline
\end{tabular}

${ }^{\mathrm{z}}$ Cells (5 g) were cultured in $400 \mathrm{~mL}$ Erlenmeyer's flasks containing $100 \mathrm{~mL}$ of MS medium supplemented with $2 \%$ sucrose.

${ }^{\mathrm{y}}$ Data represent mean values of 3 replicates; each experiment was repeated twice. Mean separation within column by Duncan's multiple range test at $p \leq 0.05$. of NAA was superior in terms of biomass accumulation and the medium supplemented with $3.0 \mathrm{mg} \cdot \mathrm{L}^{-1} \mathrm{NAA}$ yielded optimum results (Table 1 ). In this medium, $131.8 \mathrm{~g} \cdot \mathrm{L}^{-1}$ fresh biomass and $7.6 \mathrm{~g} \cdot \mathrm{L}^{-1}$ of dry biomass was recorded and growth ratio (2.68) was also optimum with this treatment

Depending on MS salt strength, it was observed that full strength MS medium was found suitable for both fresh $\left(124.6 \mathrm{~g} \cdot \mathrm{L}^{-1}\right)$ and dry $\left(6.0 \mathrm{~g} \cdot \mathrm{L}^{-1}\right)$ biomass accumulation and growth rate was also optimum (1.91) with this treatment. Lower (0.5) and higher salt strength (1.5 and 2.0) did not favor the biomass accumulation (Table 2).

Several concentrations of sucrose were supplemented in MS medium and it was observed that 3\% sucrose was suitable for biomass accumulation (Table 3). Optimum of $130.0 \mathrm{~g} \cdot \mathrm{L}^{-1}$ fresh biomass and $6.9 \mathrm{~g} \cdot \mathrm{L}^{-1}$ dry biomass was accumulated and growth ratio of cells was also optimum

Table 2. Eurycoma longifolia flask-scale cell suspension culture: effect of salt strength on accumulation of biomass after 30 days of culture. ${ }^{\mathrm{z}, \mathrm{y}}$

\begin{tabular}{lccc}
\hline $\begin{array}{l}\text { MS medium } \\
\text { salt strength }\end{array}$ & $\begin{array}{c}\text { Fresh weight } \\
\left(\mathrm{g} \cdot \mathrm{L}^{-1}\right)\end{array}$ & $\begin{array}{c}\text { Dry weight } \\
\left(\mathrm{g} \cdot \mathrm{L}^{-1}\right)\end{array}$ & $\begin{array}{c}\text { Growth } \\
\text { ratio }\end{array}$ \\
\hline 0.5 & $88.8 \mathrm{ab}$ & $4.7 \mathrm{~b}$ & $1.25 \mathrm{c}$ \\
1.0 & $124.6 \mathrm{a}$ & $6.0 \mathrm{a}$ & $1.91 \mathrm{a}$ \\
1.5 & $76.9 \mathrm{~b}$ & $5.1 \mathrm{ab}$ & $1.46 \mathrm{~b}$ \\
2.0 & $68.9 \mathrm{~b}$ & $4.8 \mathrm{ab}$ & $1.32 \mathrm{bc}$ \\
\hline
\end{tabular}

${ }^{\mathrm{z}}$ Cells (5 g) were cultured in $400 \mathrm{~mL}$ Erlenmeyer's flasks containing $100 \mathrm{~mL}$ of MS medium supplemented $3 \mathrm{mg} \cdot \mathrm{L}^{-1}$ NAA and 2\% sucrose.

${ }^{\mathrm{y}}$ Data represent mean values of 3 replicates; each experiment was repeated twice. Mean separation within column by Duncan's multiple range test at $p \leq 0.05$.

Table 3. Eurycoma longifolia flask-scale cell suspension culture: effect of sucrose concentration on accumulation of biomass after 30 days of culture.

\begin{tabular}{lccc}
\hline $\begin{array}{l}\text { Sucrose } \\
(\%, \mathrm{w} / \mathrm{v})\end{array}$ & $\begin{array}{c}\text { Fresh weight } \\
\left(\mathrm{g} \cdot \mathrm{L}^{-1}\right)\end{array}$ & $\begin{array}{c}\text { Dry weight } \\
\left(\mathrm{g} \cdot \mathrm{L}^{-1}\right)\end{array}$ & $\begin{array}{c}\text { Growth } \\
\text { ratio }\end{array}$ \\
\hline 0 & $6.1 \mathrm{~d}$ & $0.5 \mathrm{~d}$ & $0.00 \mathrm{~d}$ \\
1 & $88.8 \mathrm{~b}$ & $4.0 \mathrm{c}$ & $0.91 \mathrm{~cd}$ \\
3 & $130.0 \mathrm{a}$ & $6.9 \mathrm{a}$ & $2.34 \mathrm{a}$ \\
5 & $96.9 \mathrm{~b}$ & $6.1 \mathrm{~b}$ & $1.93 \mathrm{~b}$ \\
7 & $66.2 \mathrm{c}$ & $6.2 \mathrm{~b}$ & $1.98 \mathrm{~b}$ \\
\hline
\end{tabular}

${ }^{\mathrm{z}}$ Cells (5 g) were cultured in $400 \mathrm{~mL}$ Erlenmeyer's flasks containing $100 \mathrm{~mL}$ of MS medium supplemented $3 \mathrm{mg} \cdot \mathrm{L}^{-1} \mathrm{NAA}$. ${ }^{\mathrm{y}}$ Data represent mean values of 3 replicates; each experiment was repeated twice. Mean separation within column by Duncan's multiple range test at $p \leq 0.05$. 
Table 4. Eurycoma longifolia flask-scale cell suspension culture: effect of $\mathrm{NH}_{4}^{+}: \mathrm{NO}_{3}{ }^{-}$concentration on accumulation of biomass after 30 days of culture.

\begin{tabular}{lccc}
\hline $\begin{array}{l}\mathrm{NH}_{4}^{+}: \mathrm{NO}_{3}^{-} \\
(\mathrm{mM})\end{array}$ & $\begin{array}{c}\text { Fresh weight } \\
\left(\mathrm{g} \cdot \mathrm{L}^{-1}\right)\end{array}$ & $\begin{array}{c}\text { Dry weight } \\
\left(\mathrm{g} \cdot \mathrm{L}^{-1}\right)\end{array}$ & $\begin{array}{c}\text { Growth } \\
\text { ratio }\end{array}$ \\
\hline $0: 60$ & $115.4 \mathrm{a}$ & $6.5 \mathrm{a}$ & $2.13 \mathrm{a}$ \\
$10: 50$ & $108.7 \mathrm{ab}$ & $5.4 \mathrm{~b}$ & $1.59 \mathrm{~b}$ \\
$20: 40$ & $105.1 \mathrm{ab}$ & $5.0 \mathrm{~b}$ & $1.40 \mathrm{~b}$ \\
$30: 30$ & $98.7 \mathrm{bc}$ & $4.0 \mathrm{c}$ & $0.93 \mathrm{c}$ \\
$40: 20$ & $91.3 \mathrm{~cd}$ & $4.3 \mathrm{c}$ & $1.08 \mathrm{c}$ \\
$50: 10$ & $81.2 \mathrm{~d}$ & $3.9 \mathrm{c}$ & $0.87 \mathrm{~d}$ \\
$60: 0$ & $56.7 \mathrm{e}$ & $2.9 \mathrm{~d}$ & $0.40 \mathrm{e}$ \\
\hline
\end{tabular}

${ }^{\mathrm{z}}$ Cells (5 g) were cultured in $400 \mathrm{~mL}$ Erlenmeyer's flasks containing $100 \mathrm{~mL}$ of MS medium supplemented $3 \mathrm{mg} \cdot \mathrm{L}^{-1} \mathrm{NAA}$ and $3 \%(\mathrm{w} / \mathrm{v})$ sucrose.

${ }^{\mathrm{y}}$ Data represent mean values of 3 replicates; each experiment was repeated twice. Mean separation within column by Duncan's multiple range test at $p \leq 0.05$.
(2.34). MS medium was supplemented with varied concentration of $\mathrm{NH}_{4}{ }^{+}: \mathrm{NO}_{3}{ }^{-}$0:30, 5:25, 10:20, 15:15, 20:10, 25:5 and $30: 0 \mathrm{mM}$ were tested and results are presented in Table 4. It is evident that increase in the concentration of ammonium nitrogen decreases the biomass accumulation, whereas increase in nitrate nitrogen was responsible for the increase in biomass growth. The maximum biomass accumulation was with $0: 60 \mathrm{mM} \mathrm{NH}: \mathrm{NO}_{3}$ and $115.4 \mathrm{~g} \cdot \mathrm{L}^{-1}$ fresh biomass and $6.5 \mathrm{~g} \cdot \mathrm{L}^{-1}$ dry biomass was recorded.

\section{Optimization of bioprocess parameters in balloon type bubble bioreactors}

After optimization of medium parameters for biomass accumulation in flask-scale cultures, cell suspension cultures were established using $5 \mathrm{~L}$ capacity airlift bioreactors containing $3 \mathrm{~L}$ of modified MS medium supplemented with $3.0 \mathrm{mg} \cdot \mathrm{L}^{-1} \mathrm{NAA}$ and $3 \%(\mathrm{w} / \mathrm{v})$ sucrose (Fig. 1C). Plant cell suspensions are initiated using relatively high cell

Table 5. Eurycoma longifolia cell suspension culture in bioreactors: effect of inoculum density on biomass accumulation and production of bioactive compounds after 30 days of culture.,

\begin{tabular}{lccccc}
\hline $\begin{array}{l}\text { Inoculum density } \\
\left(\mathrm{g} \cdot \mathrm{L}^{-1}\right)\end{array}$ & $\begin{array}{c}\mathrm{FW} \\
\left(\mathrm{g} \cdot \mathrm{L}^{-1}\right)\end{array}$ & $\begin{array}{c}\mathrm{DW} \\
\left(\mathrm{g} \cdot \mathrm{L}^{-1}\right)\end{array}$ & $\begin{array}{c}\text { Growth } \\
\text { ratio }\end{array}$ & $\begin{array}{c}\text { Phenolics } \\
\left(\mathrm{mg} \cdot \mathrm{g}^{-1} \mathrm{DW}\right)\end{array}$ & $\begin{array}{c}\text { Flavonoids } \\
\left(\mathrm{mg} \cdot \mathrm{g}^{-1} \mathrm{DW}\right)\end{array}$ \\
\hline 40 & $329.81 \mathrm{c}$ & $14.50 \mathrm{bc}$ & $6.50 \mathrm{~b}$ & $7.53 \mathrm{a}$ & $1.62 \mathrm{~b}$ \\
50 & $356.60 \mathrm{a}$ & $15.39 \mathrm{a}$ & $7.53 \mathrm{a}$ & $7.72 \mathrm{a}$ & $1.74 \mathrm{a}$ \\
60 & $342.63 \mathrm{~b}$ & $14.81 \mathrm{~b}$ & $5.47 \mathrm{c}$ & $6.70 \mathrm{~b}$ & $1.63 \mathrm{~b}$ \\
70 & $321.55 \mathrm{~d}$ & $14.54 \mathrm{bc}$ & $4.01 \mathrm{~d}$ & $6.15 \mathrm{c}$ & $1.55 \mathrm{~b}$ \\
80 & $310.75 \mathrm{e}$ & $14.25 \mathrm{c}$ & $3.30 \mathrm{e}$ & $4.71 \mathrm{~d}$ & $1.46 \mathrm{c}$ \\
\hline
\end{tabular}

${ }^{\mathrm{z}}$ Cells were cultured in $3 \mathrm{~L}$ capacity balloon type bubble bioreactors containing $2 \mathrm{~L}$ of MS medium for supplemented with $3.0 \mathrm{mg} \cdot \mathrm{L}^{-1} \mathrm{NAA}, 3 \%(\mathrm{w} / \mathrm{v})$ sucrose.

${ }^{y}$ Data represent mean values of 3 replicates; each experiment was repeated twice. Mean separation within column by Duncan's multiple range test at $p \leq 0.05$.

Table 6. Eurycoma longifolia cell suspension culture in bioreactors: effect of aeration rate on biomass accumulation and production of bioactive compounds after 30 days of culture.

\begin{tabular}{lccccc}
\hline $\begin{array}{l}\text { Aeration rate } \\
(\mathrm{vvm})\end{array}$ & $\begin{array}{c}\mathrm{FW} \\
\left(\mathrm{g} \cdot \mathrm{L}^{-1}\right)\end{array}$ & $\begin{array}{c}\mathrm{DW} \\
\left(\mathrm{g} \cdot \mathrm{L}^{-1}\right)\end{array}$ & $\begin{array}{c}\text { Growth } \\
\text { ratio }\end{array}$ & $\begin{array}{c}\text { Phenolics } \\
\left(\mathrm{mg} \cdot \mathrm{g}^{-1} \mathrm{DW}\right)\end{array}$ & $\begin{array}{c}\text { Flavonoids } \\
\left(\mathrm{mg} \cdot \mathrm{g}^{-1} \mathrm{DW}\right)\end{array}$ \\
\hline 0.05 & $324.92 \mathrm{ab}$ & $13.40 \mathrm{ab}$ & $3.31 \mathrm{~b}$ & $9.55 \mathrm{~b}$ & $2.74 \mathrm{~b}$ \\
0.1 & $356.13 \mathrm{ab}$ & $14.21 \mathrm{ab}$ & $3.57 \mathrm{ab}$ & $10.26 \mathrm{a}$ & $3.62 \mathrm{a}$ \\
0.2 & $320.01 \mathrm{c}$ & $13.31 \mathrm{ab}$ & $3.28 \mathrm{~b}$ & $9.24 \mathrm{~b}$ & $2.67 \mathrm{~b}$ \\
0.3 & $256.30 \mathrm{~d}$ & $12.70 \mathrm{~b}$ & $3.09 \mathrm{c}$ & $8.02 \mathrm{c}$ & $2.29 \mathrm{~b}$ \\
$0.05-0.3^{\mathrm{x}}$ & $361.26 \mathrm{a}$ & $14.70 \mathrm{a}$ & $3.73 \mathrm{a}$ & $10.33 \mathrm{a}$ & $3.89 \mathrm{a}$ \\
\hline
\end{tabular}

${ }^{\mathrm{z}}$ Cells $\left(50.0 \mathrm{~g} \cdot \mathrm{L}^{-1}\right)$ were cultured in $3 \mathrm{~L}$ capacity balloon type bubble bioreactors containing $2 \mathrm{~L}$ of MS medium for supplemented with $3.0 \mathrm{mg} \cdot \mathrm{L}^{-1} \mathrm{NAA}, 3 \%(\mathrm{w} / \mathrm{v})$ sucrose.

${ }^{\mathrm{y}}$ Data represent mean values of 3 replicates; each experiment was repeated twice. Mean separation within column by Duncan's multiple range test at $p \leq 0.05$.

${ }^{\mathrm{x}}$ Aeration rate was gradually increased from 0.05 to $0.3 \mathrm{vvm}$ at every 7 days intervals. 
concentrations, as there is a minimum inoculation density below which growth does not occur or is preceded by a lag phase. The effect of different inoculum density were tested, and the results are presented in Table 5. The maximum cell fresh $\left(356.60 \mathrm{~g} \cdot \mathrm{L}^{-1}\right.$; Fig. 1D) and dry biomass $\left(7.53 \mathrm{~g} \cdot \mathrm{L}^{-1}\right)$ were measured at an inoculum density of 50 $\mathrm{g} \cdot \mathrm{L}^{-1}$. The higher concentration of phenolics $\left(7.72 \mathrm{mg} \cdot \mathrm{g}^{-1}\right.$ DW) and flavonoids (1.74 $\left.\mathrm{mg} \cdot \mathrm{g}^{-1} \mathrm{DW}\right)$ were also obtained at an inoculum density of $50 \mathrm{~g} \cdot \mathrm{L}^{-1}$ (Table 5 ).

The cultures were aerated with various rate of constant air supply throughout the culture period, or with an increased rate of air supply every 7-days to verify the most appropriate aeration rate for the accumulation of biomass and phenolics (Table 6). Root fresh and dry biomass decreased with the increasing aeration rate throughout culture period (Table 6). The maximum cell growth was measured with increment of air supply at every 7 days i.e., the aeration rate was controlled at $0.05 \mathrm{vvm}$ and increased to $0.1,0.2$, and 0.3 vvm after 7, 14, and 21 days, respectively. Accumulation of phenolics and flavonoids in the cultured cells were also maximum with increment in air supply and an optimum of $10.33 \mathrm{mg} \cdot \mathrm{g}^{-1} \mathrm{DW}$ of phenolics and $3.89 \mathrm{mg} \cdot \mathrm{g}^{-1} \mathrm{DW}$ of flavonoids were recorded (Table 6).

\section{Optimization of extraction of bioactive compounds from cell biomass}

Among various concentrations of methanol and ethanol as solvent for extraction of bioactive compounds, optimal phenolics (11.8 $\left.\mathrm{mg} \cdot \mathrm{g}^{-1} \mathrm{DW}\right)$ and flavonoids $\left(3.2 \mathrm{mg} \cdot \mathrm{g}^{-1} \mathrm{DW}\right)$ were obtained when $60 \%$ ethanol was used as extraction solvent (Fig. 2A). Free radical scavenging activity on DPPH was also high in this treatment (Fig. 2B). Other solvents, $40,60,80$ and $100 \%$ methanol and 40, 80 and $100 \%$ ethanol were not efficient for the extraction of bioactive compounds from cell biomass of E. longifolia as the yield of bioactive compounds was lower when they are used as solvents for extraction.

\section{Discussion}

\section{Optimization of medium parameters in flask-scale cell suspension cultures}

It was reported that type and concentration of auxin alters dramatically the growth of cells and accumulation of biomass in cell suspensions (Murthy et al., 2014; Ramachandra Rao and Ravishankar, 2002). The E. longifolia cells suspension cultures were supplemented with NAA and IBA $(0.5,1.0$, 3.0, 5.0 and $7.0 \mathrm{mg} \cdot \mathrm{L}^{-1}$ ) and the results showed that IBA supplemented medium was superior biomass accumulation
(Table 1). Medium supplemented with $3.0 \mathrm{mg} \cdot \mathrm{L}^{-1} \mathrm{NAA}$ yielded optimum biomass $\left(131.8 \mathrm{~g} \cdot \mathrm{L}^{-1}\right.$ fresh biomass and $7.6 \mathrm{~g} \cdot \mathrm{L}^{-1}$ of dry biomass) cultured cells and it was also responsible for highest growth rate (2.68). In contrast to the current results, supplementation of IBA was found superior for proliferation of adventitious roots in ginseng when compared to NAA and on the medium supplemented with IBA roots were involved in profuse branching and multiplication of additional roots which accounted for over-all biomass accumulation (Jeong et al., 2009). Impact of growth regulators on induction of cell or organ proliferation and biomass accumulation is species specific event and therefore, type and concentration of growth regulator supplementation should be assessed individually.

The optimum nutrient concentration is a critical determinant in controlling growth of the cells/organ and biomass accumulation (Paek et al., 2009) and it should be assessed and fixed in the initial stages of cultures. Half strength MS medium was reported to be suitable for biomass accumulation in adventitious root cultures of Echinacea angustifolia (Wu et al., 2006), whereas, full strength MS medium was suitable for biomass accumulation in Withania somnifera cell cultures (Praveen and Murthy, 2010). In the present experiments, it was observed that full strength MS medium was found suitable for biomass accumulation (Table 2).

Plant cell cultures are usually grown heterotrophically using simple sugars and carbon sources and the levels of sucrose has been shown to affect the biomass accumulation during suspension cultures (Ramachandra Rao and Ravishankar, 2002). The results of present work showed that $3 \%$ sucrose $(\mathrm{w} / \mathrm{v})$ was found suitable for biomass accumulation in cell suspension cultures of E. longifolia (Table 3). Similar to the current results, 3\% sucrose was found suitable for biomass accumulation in cell suspension cultures of Gymnema sylvestre (Nagella et al., 2011), whereas, 2\% sucrose was found suitable for biomass accumulation in shoot cultures of Bacopa monnieri (Naik et al., 2010). These results suggest that initial sucrose concentration in the culture media is important for the growth of suspended cells and its effect is specific for a particular plant species. Macro-elements especially nitrogen play an important role in biomass accumulation in cultured cells and organs (Paek et al., 2009). It was reported that $\mathrm{NH}_{4}: \mathrm{NO}_{3}$ ratio affected the biomass accumulation in shoot cultures of Bacopa monnieri (Naik et al., 2011), adventitious root cultures of Withania somnifera (Murthy and Praveen, 2012) and cell suspension cultures of Gymnema sylvestre (Praveen et al., 2011). The results of current studies showed that 0:60 mM NH $4: \mathrm{NO}_{3}$ 
was responsible for highest biomass accumulation (115.4 $\mathrm{g} \cdot \mathrm{L}^{-1}$ fresh biomass and $6.5 \mathrm{~g} \cdot \mathrm{L}^{-1}$ dry biomass) among the varied concentration of $\mathrm{NH}_{4}: \mathrm{NO}_{3}$ tested (Table 4).

\section{Optimization of bioprocess parameters in balloon type bubble bioreactors}

Inoculum density is an important factor affecting the growth and the production of bioactive compounds in a number of culture systems. For instance, high inoculum density stimulated root growth but inhibited biosynthesis of phenolics and flavonoids in Echinacea purpurea (Wu et al., 2006) and eleutherosides in Eleutherococcus koreanum (Lee et al., 2011). In addition, the anthocyanin composition can be changed by cell inoculum size in strawberry suspension culture (Sakurai et al., 1996). In Dendrobium candidum protocorom suspension cultures, protocrom growth and biosynthesis of phenolics, flavonoids, and polysaccharides were affected by inoculum size (Cui et al., 2014). In the present study, Inoculum density of $50 \mathrm{~g} \cdot \mathrm{L}^{-1}$ was found suitable for both biomass accumulation and metabolites production (Table 5). Lower $\left(40 \mathrm{~g} \cdot \mathrm{L}^{-1}\right)$ and higher $(60-80$ $\mathrm{g} \cdot \mathrm{L}^{-1}$ ) inocula have reduced both biomass and metabolite accumulation.

Aeration rate in the bioreactors is an important factor which controls the accumulation of biomass and the production of metabolites, because it is meant for biomass circulation and also it provides essential gaseous composition of the medium (Thanh et al., 2006 a,b; Jeong et al., 2009). The accumulation of cell biomass and secondary metabolites varies with the plant species and the type of explant used. For instance, in Echinacea purpurea, a constant aeration rate of $0.1 \mathrm{vvm}$ was optimal for adventitious root growth compared at high aeration rate (Jeong et al., 2009). In contrast, in suspension cultures of Morinda citrifola, constant aeration of $0.3 \mathrm{vvm}$ resulted in the most cell growth (Ahmed et al., 2008). In bioreactor culture, a gradual increase in aeration rate is often favorable for optimal cell growth because of the high inflow of air agitating the cell, thereby elevating the oxygen concentration in the culture, resulting in accelerated cell growth (Cui et al., 2014; Lee et al., 2011). The increment in aeration rate from $0.05 \mathrm{vvm}$ to $0.1,0.2$, and $0.3 \mathrm{vvm}$ after 7,14 , and 21 days was good enough for increasing the production of both cell biomass and bioactive compounds in the present study (Table 6).

\section{Optimization of extraction of bioactive compounds from cell biomass}

The extraction of bioactive compounds from the medicinal plant raw material is very important to obtain better yield for qualitative and quantitative studies (Azmir et al., 2013). The most common factors affecting the extraction process are matrix properties of plant part, solvent and temperature (Hernandez et al., 2009). In the current studies, among the various solvents (distilled water, ethanol and methanol) tested, $60 \%$ ethanol was found suitable for extraction of phenolics and flavonoids from cell biomass of E. longifolia (Fig. 2A) and the free radical scavenging activity on DPPH was also high with this treatment (Fig. 2B). Various solvents are used for extraction of bioactive solvents from medicinal plant raw material and a solvent which is economical, environmentally friendly and effective in mass transfer is selected as suitable solvent for extraction (Azmir et al., 2013). For instance, Kim et al. (2007) reported that $70 \%$ ethanol found superior for ginsenosides extraction from Panax ginseng adventitious roots, whereas, $60 \%$ ethanol was found superior for the extraction of caffeic acid derivatives from adventitious roots of Echinacea purpurea (Wu et al., 2008). However, treatment with $80 \%$ methanol was found suitable for extraction of phenolics and flavonoids from protocorm biomass of Dendrobium candidum (Cui et al., 2014).

Bioreactor culture system provides better advantages than traditional tissue culture system for large scale production of biomass, and bioreactor-based systems have been developed for the production ginsenosides (Paek et al., 2009) and phenolics (Wu et al., 2007). In the present study, various medium parameters such as suitability of medium, salt strength, type and concentration of auxin, sucrose and nitrogen concentration which affect biomass accumulation were established at flask-scale. Subsequently, bioreactor cultures were established and inoculum density and aeration rate were standardized for biomass and accumulation of phenolics and flavonoids. Suitable extraction method which was also achieved to be a heat reflux method. The procedure developed here is simple and it can be used for the production of bioactive phenolics from cell suspension cultures of E. longifolia.

\section{Literature Cited}

Ahmed, S., E.J. Hahn, and K.Y. Paek. 2008. Aeration volume and photosynthetic photon flux affect cell growth and secondary metabolite contents in bioreactor cultures of Morinda citrifolia. J. Plant Biol. 51:209-302.

Azmir, J., I.S.M. Zaidul, M.M. Rahman, K.M. Sharif, A. Mohamed, F. Sahena, M.H.A. Jahurul, K. Ghafoor, N.A.N. Norulaini, and A.K.M. Omar. 2013. Techniques for extraction of bioactive compounds form plant materials: A review. J. Food Eng. 117:426-436. 
Bhat, R., and A.A. Karim. 2010. Tonkat ali (Eurycoma longifolia Jack): a review on its ethnobotany and pharmacological importance. Fitoterapia 81:669-679.

Brand-William, W., M.E. Cuvelier, and C. Berset. 1995. Use of a free radical method to evaluate antioxidant activity. LWT - Food Sci. Technol. 28:25-30.

Cui, H.Y., H.N. Murthy, S.H. Moh, Y.Y. Cui, E.J. Lee, and K.Y. Paek. 2014. Production of biomass and bioactive compounds in protocorm cultures of Dendrobium candidum Wall ex Lindl. using balloon type bubble bioreactors. Ind. Crops Prod. 53:28-33.

Hernandez, Y., M.G. Lobo, and M. Gonzalez. 2009. Factors affecting simple extraction in a liquid chromatographic determination organic acids in papaya and pineapple. Food Chem. 114:734-741.

Jeong, J.A., C.H. Wu, H.N. Murthy, E.J. Hahn, and K.Y. Paek. 2009. Application of airlift bioreactor system for the production of adventitious root biomass and caffeic acid derivatives of Echinacea purpurea. Biotechnol. Bioprocess Eng. 14:91-98.

Kim, S.J., H.N. Murthy, E.J. Hahn, H.L. Lee, and K.Y. Paek. 2007. Parameters affecting the extraction of ginsenosides form the adventitious roots of ginseng (Panax ginseng C.A. Meyer). Sep. Pur. Technol. 56:401-406.

Lee, E.J., S.H. Moh, and K.Y. Paek. 2011. Influence of inoculum density and aeration volume on biomass and bioactive compound production in bulb-type bubble bioreactor cultures of Eleutherococcus koreanum Nakai. Bioresource Technol. 102:7165-7170.

Murashige, T., and F. Skoog. 1962. A revised medium for rapid growth and bioassay with tobacco tissue culture. Phys. Plant. 15:473-497.

Murthy, H.N., E.J. Lee, and K.Y. Paek. 2014. Production of secondary metabolites from cell and organ cultures: strategies and approaches for biomass improvement and metabolite accumulation. Plant Cell Tiss. Org. Cult. 118:1-16.

Murthy, H.N., and N. Praveen. 2012. Influence of macro elements and nitrogen source on adventitious root growth and withanolideA production in Withania somnifera (L.) Dunal. Natural Product Res. 26:466-473.

Nagella, P., I.M. Chung, and H.N. Murthy. 2011. In vitro production of gymnemic acid from cell suspension cultures of Gymnema sylvestre R. Br. Eng. Life Sci. 11:537-540.

Naik, P.M., S.H. Manohar, and H.N. Murthy. 2011. Effect of macroelements and nitrogen source on biomass accumulation and bacoside A production from adventitious shoot cultures of Bacopa monnieri (L.). Acta Physiol. Plant. 33:1553-1557.

Naik, P.M., S.H. Manohar, N. Praveen, and H.N. Murthy. 2010. Effect of sucrose and $\mathrm{pH}$ levels on in vitro shoot regeneration from leaf explants of Bacopa monnieri and accumulation of bacoside $\mathrm{A}$ in regenerated shoots. Plant Cell Tiss. Org. Cult. 100:235-239.

Paek, K.Y., H.N. Murthy, E.J. Hahn, and J.J. Zhong. 2009. Large scale culture of ginseng adventitious roots for production of ginsenosides. Adv. Biochem. Eng. Biotechnol. 113:151-176.

Perry, L.M. 1980. Medicinal plants of East and Southeast Asia: attributed properties and uses, MIT Press, Massachusetts, USA.

Praveen, N., H.N. Murthy, and I.M. Chung. 2011. Improvement of growth and gymnemic acid production by altering the macro elements concentration and nitrogen source supply in cell suspension cultures of Gymnema sylvestre R. Br. Ind. Crops Prod. 33:282-286.

Praveen, N. and H.N. Murthy. 2010. Establishment of cell suspension cultures in Withania somnifera for the production of withanolide A. Bioresource Technol. 101:6735-6739.

Purwanthiningsih, A.H. Husain, and K.L. Chan. 2011. Free radical scavenging activity of the standard ethanolic extract of Eurycoma longifolia (TAF-273). Inter. J. Pharma. Pharmaceut. Sci. 3:344-347.

Ramachandra Rao, S. and G.A. Ravishankar. 2002. Plant cell cultures: chemical factories of secondary metabolites. Biotechnol. Adv. 20:101-153.

Sakurai, M., T. Mori, M. Seki, and S. Furusaki. 1996. Changes of anthocyanin composition by conditioned medium and cell inoculum size using strawberry suspension culture. Biotechnol. Lett. 18:1149-1154.

Slinkard, K., and V.L. Singleton. 1977. Total phenol analysis: automation and comparison with manual methods. Am. J. Enol. Viticul. 28:49-55.

Thanh, N.T., H.N. Murthy, D.M. Pandey, K.Y. Yu, E.J. Hahn, and K.Y. Paek. 2006a. Effect of carbon dioxide on cell growth and saponin production in suspension culture of Panax ginseng. Biol. Plant. 50:752-754.

Thanh, N.T., H.N. Murthy, K.W. Yu, C. Seung Jeong, E.J. Hahn, and K.Y. Paek. 2006b. Effect of oxygen supply on cell growth and saponin production in bioreactor cultures of Panax ginseng. J. Plant Physiol. 163:1337-1341.

Wu, C.H., H.N. Murthy, E.J. Hahn, H.L. Lee, and K.Y. Paek. 2008. Efficient extraction of caffeic acid derivatives from adventitious roots of Echinacea purpurea. Czech J. Food Sci. 26:254-258.

Wu, C.H., H.N. Murthy, E.J. Hahn, and K.Y. Paek. 2007. Enhanced production of caftaric acid, chlorogenic acid and cichoric acid in suspension cultures of Echinacea purpurea by the manipulation of incubation temperature and photoperiod. Biochem. Eng. J. 36:301-303.

Wu, C.H., Y.H. Dewir, E.J. Hahn, and K.Y. Paek. 2006. Optimization of culturing conditions for the production of biomass and phenolics from adventitious roots of Echinacea purpurea. J. Plant Biol. 49:193-199.

Zhuang, X., P.Y.Y. Lu, and G.S. Yang. 1992. Extraction and determination of flavonoid in ginkgo. Chinese Herb. Med. 23:122-124. 